\title{
VISITORS PERCEPTION OF EVENTS: A SAMPLE OF AYDER SNOWMAN FESTIVAL
}

Özge GÜDÜ DEMIRBULAT*, Gencay SAATCI **

* Balıkesir Üniversitesi*, Uludağ Üniversitesi**

E-mail: ozgegudu@hotmail.com*,gencaysaatc1@uludağ.edu.tr**

Copyright (C) 2015 Özge GÜDÜ DEMİRBULAT, Gencay SAATCI. This is an open access article distributed under the Eurasian Academy of Sciences License, which permits unrestricted use, distribution, and reproduction in any medium, provided the original work is properly cited.

\begin{abstract}
In today's tourism market, local events, that come up with people's desire to understanding of different cultures and engaging in cultural activities and meeting the people's desire to spend their vocation time with fun activities, is located at the level of undeniable importance. Snowman Festival, organized in Ayder Highland, Çamlihemşin, Rize, is one of the local events that slightly more developed and began to appeal to a wideraudience everyyear. It is possible to say that local actvities with in the scope of the festival bring about socio-cultural, economic and environmental changes in the region. In the study, socio-cultural, economic and environmental impacts of the Snowman Festival on tourists have been studied to reveal. And then, the perception of tourists about the events were trying to learn. For this purpose, a conceptual framework was created primarily for local events. Then, a research has been conducted on domestic tourists who join Snowman Festival, organized for 8th at 31 January-1 February 2015, made and the results of the research discussed. According to research results, it is possible to say that local events, providing a gain in all of the cultural and social fields.
\end{abstract}

Keywords: Events; Local Events; Tourism Impacts; Snowman Festival

\section{Etkinliklere Yönelik Ziyaretçi Algıları: Ayder Kardan Adam Şenliği Örneği ${ }^{1}$}

\section{ÖZET}

İnsanların farklı kültürleri tanıma ve kültürel etkinliklerde bulunma arzusu ve tatil zamanlarını eğlenceli faaliyetlerle geçirme isteklerini karşılama potansiyelleri ile öne çıkan yerel etkinlikler, günümüz turizm pazarında önemi yadsınamayacak düzeyde yer almaktadır. Her geçen yıl biraz daha gelişen ve daha geniş kitlelere hitap etmeye başlayan yöresel etkinliklerden bir tanesi de Rize İli Çamlıhemşin İlçesi Ayder Yaylası'nda düzenlenen Kardan Adam Şenliği'dir. Yerel etkinlikler kapsamında şenliklerin, düzenlendikleri yörede sosyokültürel, ekonomik ve çevresel değişimler meydana getirdiğinden söz etmek mümkündür. Araştırmada, Kardan Adam Şenliği'nin turistler üzerindeki sosyo-kültürel, ekonomik ve çevresel etkileri ortaya çıkarılmaya ve turistin düzenlenen etkinlik hakkındaki algıları öğrenilmeye çalışılmıştır. Bu amaçla, öncelikle yerel etkinliklere yönelik kavramsal bir

\footnotetext{
${ }^{1} \mathrm{Bu}$ çalışmanın Özet bölümü Gümüşhane'de 14-16 Mayıs 2015 tarihlerinde düzenllenen Doğu Karadeniz Bölgesi Sürdürülebilir Turizm Kongresi’nde sözlü bildiri olarak sunulmuştur.
} 
çerçeve oluşturulmuş ve 31 Ocak-1 Şubat 2015 tarihlerinde sekizinci kez düzenlenen Kardan Adam Şenliği'ne katılan yerli turistler üzerinde yürütülen araştırma sonuçları tartışılmıştır. Araştırma sonuçlarından yola çıkarak, yöresel etkinliklerin kültürel ve sosyal alanların tümünde bir kazanım sağlayabilecek nitelikte turizm faaliyeti olduğu söylenebilir.

Anahtar Kelimeler: Etkinlik; Yerel Etkinlik; Turizm Etkileri; Kardan Adam Şenliği

\section{GIRİş}

Turizm yalnızca ekonomik bir olay olmayıp, sosyal ve kültürel yönleri de olan, toplumu ve sosyal yapıyı etkileyen bir harekettir. İnsanları birbirine daha da yaklaştıran turizm hareketlerinin, gerek yerel halkın, gerekse turistlerin hayatına renk kattığını söylemek mümkündür (Şebin ve diğerleri, 2010: 28). Etkinlikler, turizm olgusunun en hızlı, eğlenceli ve canlı unsurlarından biridir (Meydan Uygur ve Çelik, 2010: 37). Etkinlikler; insanların birlikte hareket etmesi sonucunda gerçekleşen, toplumsal ya da bireysel birtakım ihtiyaçları gidermek veya bireysel olarak başarıya ulaşılamayan durumlarda, bir grup ve örgüt olarak ortak amaçlara ulaşmak, ortak bir duygu ya da düşünceyi paylaşmak ve toplumsal yaşam içinde sosyal bir varlık olabilmek gibi amaçlarla düzenlenen olaylardır (Ekin, 2011: 3). Bölgeye özgü yerel etkinlikler ise; bir şehrin veya bölgenin ruhunu yansıtan ve bölgenin söz konusu faaliyetlerle anılmasını sağlayan olaylardır. Brezilya'daki Rio De Janerio Karnavalı, Almanya Münih'teki Oktober Fesitivali ve Türkiye'de düzenlenen yerel etkinlikler, bu tür olaylara örnek olarak gösterilebilir (Kızılırmak, 2006: 183). Yerel etkinlikleri; çeşitli müzik, tiyatro gruplarının gösterisi, resim sergileri, yöresel festivaller (karpuz, kiraz festivali, deve güreşi, yağlı güreş organizasyonları, panayırlar vb.) şeklinde ifade etmek mümkündür (Atak, 2009: 54; Çulha, 2008: 1830; Gül ve diğerleri, 2013: 215).

Genel olarak, turizm faaliyetlerine doğal, tarihi, kültürel ve ekonomik varlıkların çekicilik özelliklerinin yön verdiğini ifade etmek mümkündür (Özcan, 2005: 55). Farklı turizm aktiviteleri arayışının artmasıyla, destinasyonlarda düzenlenen etkinlikler de bir turizm aracı olarak kullanılmaya başlanmıştır (Ambrosio ve diğerleri, 2011: 331). Etkinlikler, destinasyona ilave bir çekicilik unsuru eklemekle birlikte turizmin sürdürülebilir bir hal almasını da sağlamaktadır (Kömürcü, 2013: 23). Hiçbir etkinlik birbirine benzememekte ve her bir etkinlik katılımcılarına farklı deneyimler kazandırmaktadır. Öte yandan; etkinliğin gerçekleştiği destinasyonda bulunmak, o ortamı paylaşmak, turistlerin ziyaret kararını etkileyen önemli faktörlerdir (Getz, 2008: 404). Türkiye'de çeşitli il ve ilçeler kendi adlarıyla etkinlikler düzenlemektedirler. Bu organizasyonların yapılmasının temelinde, il veya ilçenin tanıtımının yapılabilmesi, ekonomik gelişmesinin sağlanması ve sahip oldukları tarımsal, doğal, kültürel ve arkeolojik açıdan sahip olunan potansiyelin değerlendirilerek turizm sektörünün gelişmesi yatmaktadır (Kızılırmak, 2006: 189).

Etkinlik turizmi kapsamında spor etkinlikleri, sanatsal, kültürel ve bilimsel etkinliklerden bahsetmek mümkündür (Kömürcü ve diğerleri, 2014: 223; Popescu ve Corboş, 2012: 19). Destinasyonlarda bulunan doğal/fiziksel turizm kaynaklarını canlandıran ve imaj oluşturan (Matheson ve diğerleri, 2014: 16) bir turizm çekiciliği olan etkinliklerin sistematik bir biçimde planlanması, geliştirilmesi ve pazarlanması, etkinlik turizmi olarak tanımlanmaktadır (Ekin, 2011: 7). Bazı destinasyonlar, turistik talebin düşük olduğu mevsimlerde talebi dengelemek için etkinlik turizmi kapsamında yerel etkinlikler düzenlemektedirler (Jackson, 
2008: 240). Etkinlikler; mevsimselliğin etkisini azaltmakta, sezon diş1 doğal çekicilikleri kullanarak önemli kazanımlar yaratabilmektedir. Birçok destinasyonda yerel halk kutlamalarını yüksek sezon dışındaki tarihlerde gerçekleştirmektedir. Bu durum ziyaretçiler için daha özgün etkinlikler gerçekleşmesine yol açmaktadır (Ekin, 2011: 8). Yerel etkinlikler genellikle küçük ölçekli, kısa süreli, daha az karmaşık ve sadece yerel medyada pazarlanma özelliği taşımaktadırlar (Koh ve Jackson, 2008: 22). Turistler, planlanmış etkinliklere katılmak aynı zamanda da gidilen destinasyonu tanımak isterler. Bu nedenle, etkinlik turizmi turistik destinasyonların tanıtımına yardımcı olmakta ve destinasyon yönetim organizasyonları tarafından destinasyonların pazarlanmasında tercih edilmektedir (Meydan Uygur ve Çelik, 2010: 37).

Yerel etkinliklerin, bir kısmının yerel yiyeceklere, bir kısmının da halk oyunlarına yönelik olduğunu ifade etmek mümkündür. $\mathrm{Bu}$ etkinlikler sayesinde insanların birbirlerinin kültürlerini (Jepson ve diğerleri, 2008: 8), gelenek ve göreneklerini tanımalarının yanında, toplumun gelişiminin de sağlanması mümkündür. Kızılırmak (2006), Türkiye'de düzenlenen yerel etkinliklerin büyük çoğunluğunun, yöresel özellikte olduğunun altını çizerek, bu etkinliklerin temelinde, yöre halkının buluşması, eğlenmesi, alışveriş yapmaları, gelenek ve göreneklerinin unutulmaması amaçlarının bulunduğunu ifade etmektedir. Bu tür etkinlikler sayesinde, aynı toplumda yer alan bireyler arasında yakın ilişkiler meydana gelebildiği gibi çok farklı kültürlerden kişiler de bir araya gelerek kültürel alışveriş sağlanabilmektedir. Bu noktada, yerel halk ile ziyaretçilerin resmi olmayan, dostça bir sosyal konumda temasa geçmesi mümkündür.

Yerel etkinlikler, yerli ve yabancı ziyaretçi sayısındaki artışla birlikte turizmin canlanmasına neden olabilmekte, dolayısıyla yerel ekonominin dinamiklerini harekete geçirmede zorlayıcı bir etki yaratabilmektedir (Kişioğlu ve Selvi, 2013: 72). Etkinliklerin, yerel toplulukların yaşamalarında önemli bir role sahip olduğunun altını çizen Gürsoy ve diğerleri (2004: 171), yöre halkı ve ziyaretçiler için düzenlenen faaliyetlerin yöre ekonomisine katkı sağladığını da ifade etmektedirler. Etkinliklerin genel olarak ekonomik etkileri; etkinliğe: katılan ziyaretçiler tarafından yapılan harcamalar, etkinlik nedeniyle gerçekleşen yatırım harcamaları ve etkinliği gerçekleştirme ile ilişkili, organizatörler tarafından yapılan harcamalar şeklinde kendini göstermektedir (Hodur ve Leistritz, 2008: 66; Kömürcü, 2013: 32). Yöresel etkinlikler kapsamında gösteri sunacak ve bunları izleyecek kişilerin, şenliğin/etkinliğin düzenlendiği yere gelmesi için ulaşım hizmetlerinden yararlanmaları, konaklamaları için otel odalarının kiralanması gibi hususların yöre ekonomisinde canlanma yaratması mümkündür. Öte yandan; etkinlikler süresince, turizm işletmelerinin doluluk oranı artabilmekte ve buna bağlı olarak işletmeler, yüksek fiyatlarla karlılıklarını daha da artırma yoluna gidebilmektedirler. Başka bir ifadeyle; yöresel etkinliği fırsat bilen yöre esnafı, ürün ya da hizmet fiyatlarını artırma yoluna gidebilmektedirler.

Yerel etkinliklerin, etkinliğin yapıldığı kentte çöp sorununa, daha fazla polisin etkinliğin bulunduğu yerde yığılmasına ve trafik kontrolünün zorlaşmasına neden olması gibi bazı olumsuzluklara sahip olduğu belirtilmektedir (Kişioğlu ve Selvi, 2013: 72). Etkinlikler kapsamında yöredeki ziyaretçi sayısının artması zaman zaman taşıma kapasitesinin aşılması sorununu beraberinde getirmektedir (Yeoman ve diğerleri, 2004: 67). Bunun yanında; bir etkinliğin organize edilmesi, etkinliğin gerçekleştiği bölgede yeni altyap1 ve üst yap1 unsurlarının inşa edilmesini ya da var olan tesislerin yeniden gözden geçirilmesini de gerektirmektedir (Kömürcü, 2013: 34). Ekinliklerin olumlu etkileri değerlendirildiğinde, destinasyonların pazarlama stratejilerine yön verdiğini söylemek mümkündür (Boo ve 
diğerleri, 2009: 51). Etkinlikler, turizm için önemli bir motivasyon aracı olarak ifade edilebildikleri gibi destinasyonların pazarlama ve gelişim planlarında etkin rol oynayabilmektedirler (Horng ve diğerleri, 2013: 195). Özel etkinlikler ile ilgili yapılan araştırmalarda, bu etkinliklerin ekonomik etkileri ve insanları bu tür olaylara çeken sebepler ve güdülerin neler olduğu üzerinde durulmaktadır (Kızılırmak, 2006: 184).

Bununla birlikte, etkinlik turizmi kapsamında literatürde yapılmış çok sayıda çalışma (Atak, 2009; Bilgili ve diğerleri, 2012; Chen, 2011; Çelik, 2009; Ekin, 2011; Gürsoy ve diğerleri, 2004; Hodur ve Leistritz, 2008; Jackson, 2008; Jones, 2001; Karagöz, 2006; Kömürcü, 2013; Morgan ve Condliffe, 2006; Tayfun ve Arslan, 2013; Yang ve diğerleri, 2010) bulunmaktadır. Özellikle bir etkinlik turizmi çeşidi olan festivallerin ekonomik, sosyal ve kültürel etkilerinin ölçülmesi amacıyla yerel halk örneklem seçilerek yapılan çalışmalar yadsınamayacak düzeydedir. $\mathrm{Bu}$ çalışmada ise, etkinlik turizminin bir başka çeşidi olan yöresel şenliklerin; sosyo-kültürel, ekonomik ve çevresel etkilerinin turistlerin bakış açısıyla değerlendirilmesine çalışılmaktadır. Getz (2008) etkinlikler kapsamında turizme arz ve talep açısından yaklaşmak gerektiğini ifade etmektedir. Öte yandan; etkinlikte yer alan faaliyetlerin tüketici perspektifinden değerlendirilmesi önemli görülmektedir. Bununla birlikte, yerel etkinlikler kapsamında özellikle şenliklerin düzenlenmesinde ev sahibi yörenin mevcut niteliklerinin de göz önüne alınması gerekmektedir.

Türkiye'de festival, şenlik, fuar, panayır hemen hemen aynı anlamlarda kullanılmakta ve tümüne ise etkinlik denilmektedir (Polat ve diğerleri, 2013: 50). T.C. Kültür ve Turizm Bakanlığı'nın verilerinden derlenen bilgilere göre; 2014 yılı içinde Türkiye'nin 81 ilinin tamamında festival, şenlik, özel gün, özel hafta ve şölen adı altında yaklaşık olarak 1304 etkinlik gerçekleştirilmiştir. Bu etkinliklerin Mayıs-A ğustos ayları arasında yoğunlaştığını söylemek mümkündür. En yoğun etkinlikler; Temmuz ve Ağustos aylarında, en az sayıda etkinlik ise Kasım'dan Mart'a kadar olan dönemde düzenlenmektedir. Rize İlinde ise 2014 yılında 22 yerel etkinlik düzenlenmiştir (http://www.tanitma.gov.tr/TR,50394/festivallerfuarlar-ve-yerel-etkinlikler-2013.html, 25.12.2014). Bu etkinliklerden biri de Çamlıhemşin Belediye Başkanlığı ve Çamlıhemşin Doğa Sporları İhtisas Spor Kulübü tarafindan düzenlenen Çamlıhemşin Ayder Kardan Adam Şenliği'dir. Bu araştırmada, yerel ekinliklere bağlı olarak yerli turistlerin turizmin etkilerin yönelik algıları incelenmektedir. Örnek olarak, Çamlıhemşin Ayder Kardan Adam Şenliği ele alınmıştır. Bu bağlamda, öncelikle yerel etkinliklere yönelik kavramsal bir çerçeve oluşturulmuş; daha sonra ise, yerli turistler üzerinde yürütülen araştırma sonuçları tartışılmıştır.

\section{YÖNTEM}

Araştırmada Ayder Yaylası'nda gerçekleştirilen, etkinlik turizmi kapsamında yer alan Kardan Adam Şenliği'nin, yerli turistler üzerindeki sosyo-kültürel, ekonomik we çevresel etkileri ortaya çıkarılmaya ve yerli turistlerin düzenlenen etkinlik hakkındaki algıları öğrenilmeye çalışılmıştır. Araştırmanın hipotezleri Tablo 1'deki gibi belirlenmiştir. 


\section{Tablo 1. Araştırma Hipotezleri}

\begin{tabular}{|l|l|}
\hline Hipotez 1 & $\begin{array}{l}\text { Yerli turistlerin Ayder Kardan Adam Şenliği'ne yönelik algıları cinsiyete } \\
\text { göre anlamlı farklılık göstermektedir. }\end{array}$ \\
\hline Hipotez 2 & $\begin{array}{l}\text { Yerli turistlerin Ayder Kardan Adam Şenliği’ne yönelik algıları daha önce } \\
\text { bir şenliğe katılıp katılmama durumuna göre anlamlı farklılık } \\
\text { göstermektedir. }\end{array}$ \\
\hline Hipotez 3 & $\begin{array}{l}\text { Yerli turistlerin Ayder Kardan Adam Şenliği’ne yönelik algıları yaşa göre } \\
\text { anlamlı farklılı göstermektedir. }\end{array}$ \\
\hline Hipotez 4 & $\begin{array}{l}\text { Yerli turistlerin Ayder Kardan Adam Şenliği'ne yönelik algıları ikamet } \\
\text { edilen yere göre anlamlı farklılık göstermektedir. }\end{array}$ \\
\hline Hipotez 5 & $\begin{array}{l}\text { Yerli turistlerin Ayder Kardan Adam Şenliği'ne yönelik algıları Ayder'de } \\
\text { kalınan süreye göre anlamlı farklılık göstermektedir. }\end{array}$ \\
\hline
\end{tabular}

Araştırma alanı olarak, Rize İli Çamlıhemşin İlçesi, Ayder Yaylası seçilmiştir. Araştırma alanı seçilmesinde, yörede düzenlenen Kardan Adam Şenliği etkili olmuştur. Araştırma evreni, Ayder Kardan Adam Şenliği'nin gerçekleştirildiği 31 Ocak 2015- 1 Şubat 2015 tarihleri arasında Ayder Yaylası'na gelen yerli ziyaretçileri kapsamaktadır.

Araştırma evreninin rakamsal olarak büyüklüğü net bir biçimde bilinmemektedir. Bu sebeple, araştırma örneklemi 31 Ocak- 1 Şubat 2015 tarihleri arasında Ayder Y'aylası'nda rastgele örnekleme yöntemiyle seçilen yerli ziyaretçilerden oluşmaktadır. Araştırma verileri anket yöntemiyle, 31 Ocak - 1 Şubat 2014 tarihleri arasında, araştırmaya katılmayı kabul eden 210 ziyaretçi üzerinde, yüz yüze görüşme yöntemiyle yapılmıştır. 210 adet katılımcı anket ifadelerini cevaplandırmış ve bunların 20 tanesi eksik veya yanlış cevaplandırıldığından değerlendirme dışına çıkarılmış, bunun üzerine 190 adet anket değerlendirmeye alınmıştır.

Araştırmanın uygulamasında veri toplama tekniği olarak nicel araştırma yöntemlerinden anket kullanılmıştır. Anket ifadeleri oluşturulurken detaylı bir yazın taraması yapılarak, ilgili çalışmalardan (Gül ve diğerleri, 2013; Tayfun ve Arslan, 2013; Kömürcü, 2013) yararlanılmıştır. Geliştirilen anket formunda 9 adet demografik ve kişisel bilgilere ait ifade ile 37 adet "Ayder Kardan Adam Şenliği”ni değerlendirmeye yönelik ifade yer almıştır. Bu ifadeler 5'li likert ile ölçeklendirilmiştir. İfadelere $1-5$ arası puan verilmiştir.

Anket çalışmasından önce olası hatalardan kaçınmak amacıyla araştırmaya yönelik ön test çalışması yapılmıştır. Yerli turistler arasından tesadüfî seçilen 22 kişi ile ön test çalışması gerçekleştirilmiş ve anlaşılmayan soruların düzeltilmesi sağlanmıştır. Ön test ile elde edilen veriler güvenilirlik analizine tabi tutulmuş ve Cronbach's Alpha değeri 0,912 olarak bulunmuştur.

Araştırmada değerlendirmeye uygun bulunan 190 adet anket formu istatistiksel analize tabi tutulmuştur. Araştırma verileri, SPSS 21.0for Windows istatistik paket programı yardımıyla analiz edilmiştir. Öte yandan, anket uygulaması gerçekleştirildikten sonra, çalışma kapsamına alınan yerli turistlerin demografik özellikleri ile Ayder Kardan Adam Şenliği'nin etkilerinin değerlendirilmesi amacıyla oluşturulan ifadelere verilen yanıtlar, yüzde, frekans, aritmetik ortalama ve standart sapma değerleri esas alınarak analiz edilmiştir. Bununla birlikte, araştırmada veriler dağılım açısından incelenmiştir. Veriler normal dağılım göstermediğinden Mann - Whitney U ve Kruskal - Wallis H analizlerinden yararlanılmıştır. Değerlendirilen tüm veriler \%95 güven aralığında incelenmiştir. 
Zaman ve maliyet kısıtının yanı sıra, söz konusu bölgede konuya ilişkin az sayıda çalışma yapılmış olması, araştırma alanı olarak bu bölgenin seçilmesinde etkili olmuştur. Bununla birlikte, kullanılan anket formlarında araştırmanın katılımcılarının samimi ve doğru yanıtlar vererek, görüş ve değerlendirmelerinde objektif davrandıkları varsayılmıştır.

\section{BULGULAR}

\section{Güvenilirlik Analizi}

Çalışma ile elde edilen veriler, SPSS 21.0 programından yararlanılarak değerlendirilmiş ve analiz edilmiştir. Araştırmada kullanılan ölçeğin güvenilirliğinin değerlendirilmesinde Cronbach's Alpha testinden yararlanılmıştır. Ölçeğinin güvenilirlik katsıyısı, 0,912 olarak bulunmuştur. $\mathrm{Bu}$ değer, ölçeğin iç tutarlılığının yüksek düzeyde olduğunu göstermektedir. Buna göre, ölçeğin güvenilir bir veri toplama aracı olduğu söylenebilir.

\section{Demografik Bulgular}

Araştırmaya katılan yerli turistlere ait demografik bilgiler ve şenliklere katılım sıklıkları, Tablo 1'de verilmektedir.

Tablo 1. Ziyaretçilere İlişkin Betimleyici İstatistikler

\begin{tabular}{|c|c|c|c|c|c|}
\hline & Siklık $(f)$ & $\begin{array}{c}\text { Yüzde } \\
\text { Dĕgeri } \\
\text { (\%) }\end{array}$ & & Siklık $(f)$ & $\begin{array}{c}\text { Yüzde Dĕ̆geri } \\
\text { (\%) }\end{array}$ \\
\hline \multicolumn{3}{|c|}{ Cinsiyet } & \multicolumn{3}{|c|}{ Meslek } \\
\hline Kadın & 97 & 51,1 & İşçi & 36 & 18,9 \\
\hline Erkek & 93 & 48,9 & Memur & 36 & 18,9 \\
\hline Toplam & 190 & 100,0 & Esnaf & 16 & 8,4 \\
\hline \multicolumn{3}{|c|}{ Yaş } & Çiftçi/Hayvancı & - & - \\
\hline 20 yaş ve altı & 28 & 14,7 & Emekli & 22 & 11,6 \\
\hline $21-30$ yaş arası & 80 & 42,1 & Serbest Meslek & 19 & 10,0 \\
\hline $31-40$ yaş arası & 35 & 18,4 & İşsiz & 8 & 4,2 \\
\hline $41-50$ yaş arası & 39 & 20,5 & Ev Hanımı & 22 & 11,6 \\
\hline 51 yaş ve üzeri & 8 & 4,2 & Diğer & 31 & 16,3 \\
\hline Toplam & 190 & 100,0 & Toplam & 190 & 100,0 \\
\hline \multicolumn{3}{|c|}{ İkamet Edilen Yer } & \multicolumn{3}{|c|}{ Şenliğe Katılım Sıklığı } \\
\hline Rize Merkez & 49 & 25,8 & İlk Kez & 96 & 50,5 \\
\hline Çamlıhemşin & 39 & 20,5 & $2-4$ aras1 & 67 & 35,3 \\
\hline Ayder Yaylası & 8 & 4,2 & $5-6$ arası & 7 & 3,7 \\
\hline Rize D1ş1 & 94 & 49,5 & $7-8$ arasi & 20 & 10,5 \\
\hline Toplam & 190 & 100,0 & Toplam & 190 & 100,0 \\
\hline \multicolumn{3}{|c|}{$\begin{array}{c}\text { Şenlik Boyunca Ayder'de Kalma } \\
\text { Süresi }\end{array}$} & \multicolumn{3}{|c|}{ Daha Önce Başka Bir Şenliğe Katıldınız mı? } \\
\hline Günübirlik & 23 & 12,1 & Evet & 152 & 80,0 \\
\hline 1 gece & 79 & 41,6 & Hayır & 38 & 20,0 \\
\hline 2 gece & 47 & 24,7 & Toplam & 190 & 100,0 \\
\hline 3 geceden fazla & 41 & 21,6 & & & \\
\hline
\end{tabular}


Katılımcıların demografik özellikleri incelendiğinde ortaya çıkan belirgin sonuçları şu şekilde özetlemek mümkündür;

- Cinsiyet dağılımına bakıldığında \%51,1'i kadın, \%48,9'u ise erkektir.

- Katılımcıların \%42,1'si, 21-30 yaş aralığında bulunmaktadır.

- Meslek gruplarına göre sınıflandırma yapıldığında; \%18,9’luk bir kısım işçi ya da memur olarak görev yapmaktadır.

- Şenliğe katılan ziyaretçilerin büyük çoğunluğu $(\% 49,5)$, Rize dişında ikamet etmektedir.

- Ayder Kardan Adam Şenlikleri'ne ilk kez katılanların sayısı genel ortalamanın $(\% 50,5)$ üzerinde bulunmaktadır.

- Ziyaretçilerin büyük çoğunluğu Ayder'de farklı geceleme sayılarında konaklama yapmaktadırlar. En fazla konaklama süresi bir gecedir. Günübirlik gelen ziyaretçilerin sayısı ise en düşük paya $(\% 12,1)$ sahiptir.

- Ziyaretçilerin büyük çoğunluğu $(\% 80,0)$, daha önceden başka bïr şenliğe katılmışlardır.

Katılımcıların, Ayder Kardan Adam Şenliği'ne tekrar gelme niyetleri, şenliğin duyurum yolu ve ziyaretçiler tarafından tavsiye edilip edilmeme durumları Tablo 2'de incelenmiştir.

Tablo 2. Ayder Kardan Adam Şenliği’ne İlişkin Betimleyici İstatistikler

\begin{tabular}{|c|c|c|}
\hline \multicolumn{3}{|c|}{$\begin{array}{c}\text { Önümüzdeki Yıl İçin Ayder Kardan Adam Şenliği’ne Gelmeyi Düşünüyor } \\
\text { Musunuz? }\end{array}$} \\
\hline & Siklık $(f)$ & Yüzde Dĕgeri (\%) \\
\hline Evet & 105 & 55,3 \\
\hline Hayır & 27 & 14,2 \\
\hline Kararsızım & 58 & 30,5 \\
\hline Toplam & 190 & 100,0 \\
\hline \multicolumn{3}{|c|}{ Ayder Kardan Adam Şenliği'nden Nasıl Haberdar Oldunuz? } \\
\hline & Siklık $(f)$ & Yüzde Dĕgeri (\%) \\
\hline Arkadaş veya akraba tavsiyesi & 104 & 54,7 \\
\hline Broşür, katalog vb. & 13 & 6,8 \\
\hline TV, gazete, dergi vb. & - & - \\
\hline Bir seyahat acentesi kanaliyla & 62 & 32,6 \\
\hline İnternet- sosyal medya & 11 & 5,8 \\
\hline Diğer & - & - \\
\hline Toplam & 190 & $\mathbf{1 0 0 , 0}$ \\
\hline \multicolumn{3}{|c|}{ Ayder Kardan Adam Şenliği’ni Çevrenizdekilere Tavsiye Eder Misiniz? } \\
\hline & Siklık $(f)$ & Yüzde Dĕgeri (\%) \\
\hline Evet & 151 & 79,5 \\
\hline Hayır & 39 & 20,5 \\
\hline Toplam & 190 & $\mathbf{1 0 0 , 0}$ \\
\hline
\end{tabular}

Katılımcıların vermiş oldukları cevaplar doğrultusunda, Ayder Kardan Adam Şenliği’ne ait ortaya çıkan betimleyici istatistikler şu şekilde özetlenebilmektedir: 
- Ziyaretçilere, gelecek yıl için de “Ayder Kardan Adam Şenliği”"ne gelmeyi düşünüp düşünmedikleri sorulduğunda; büyük çoğunluğun $(\% 55,3)$ tekrar şenliğe gelme niyetinde oldukları saptanmıştır.

- Ayder Kardan Adam Şenliği’nin arkadaş veya akraba tavsiyesi şeklinde duyurumu daha yaygindır $(\% 54,7)$.

- Genel olarak $(\% 79,5)$ katılımcılar, Ayder Kardan Adam Şenliği’ni çevrelerine tavsiye etme eğilimindedirler.

\section{Geçerlilik Analizi}

Araştırmada kullanılan ölçeğin yapı geçerliliğini incelemek için faktör analizi uygulanmıştır. Açıklayıcı faktör analizine başlamadan önce, örneklem büyüklügünün faktör analizine uygunluğunu gösteren Kaiser-Meyer-Olkin (KMO) değerleri hesaplanmış ve 0,647 olarak bulunmuştur. KMO değerlerinin 0,50 'den büyük olması örneklemin faktör analizi için yeterli olduğunu gösterdiğinden, bu veriler üzerinden faktör analizi yapılabileceği sonucuna varılmıştır. Öte yandan; ölçeğin küresellik (Bartlett's Test) derecesine bakıldığında ( $\mathrm{X}^{2}$ : 2712,478, df: 369 ve $\mathrm{p}<, 000$ ), elde edilen verilerin anlamlı farklılık gösterdiği ve faktör analizi yapmaya uygun olduğu belirlenmiştir. KMO ve Bartlett testi sonuçlarının uygunluğu belirlendikten sonra, 37 önermeye faktör analizi uygulanmıștır. Yapılan açıklayıcı faktör analizi neticesinde, "Sosyo-Kültürel Etki", "Ekonomik Etki", "Çevresel Etki", "Kişisel Kazanımlar" ve "Genel Etkiler" alt boyutlar olarak ortaya çıkmıştır. Faktör analizi sonucuna göre, faktörler toplam varyansın \%77,217'sini açıklamaktadır.

\section{İfadelere İlişkin Bulgular}

Tablo 3 incelendiğinde katılımcıların anket ifadelerine verdikleri cevapların ortalama değerleri görülmektedir. 


\section{Tablo 3. İfadelere İlişkin Bulgular}

\begin{tabular}{|c|c|c|}
\hline & 承 & 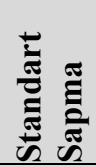 \\
\hline \multicolumn{3}{|l|}{ Sosyo-Kültürel Etkiler } \\
\hline Ayder Kardan Adam Şenliği, yerel kültürün korunmasına yardımcı olmaktadır. & 3,44 & ,90 \\
\hline Ayder Kardan Adam Şenliği, yörenin kültürel ve sosyal gelişimini artırmaktadır. & 3,66 & ,86 \\
\hline $\begin{array}{l}\text { Ayder Kardan Adam Şenliği, geleneksel kültürrün gelecek kuşaklara aktarılmasını } \\
\text { sağlamaktadır. }\end{array}$ & 3,74 & ,92 \\
\hline Ayder Kardan Adam Şenliği sayesinde yeni insanlarla tanışma firsatım oldu. & 3,78 & ,88 \\
\hline Ayder Kardan Adam Şenliği yörenin kültürünü yansıtmaktadır. & 3,52 & ,79 \\
\hline Ayder Kardan Adam Şenliği, yerel halk ile turistlerin iletişim kurmasını sağlamaktadır. & 3,51 & ,90 \\
\hline $\begin{array}{l}\text { Ayder Kardan Adam Şenliği, yerel örgütler/işletmeler/kurumlar arası işbirliğini } \\
\text { artırmaktadır. }\end{array}$ & 3,54 & ,85 \\
\hline Ayder Kardan Adam Şenliği, yerel halkın dayanışma bilincini geliştirmektedir. & 3,61 & ,74 \\
\hline \multicolumn{3}{|l|}{ Ekonomik Etkiler } \\
\hline Ayder'deki yeme-içme fiyatları uygundur. & 3,72 & 1,14 \\
\hline Ayder'deki konaklama fiyatlart uygundur. & 3,73 & 1,03 \\
\hline Ayder'deki konaklama imkânları yeterlidir. & 3,61 & 1,02 \\
\hline Ayder'de alışveriş imkânları yeterli düzeydedir. & 3,42 & 1,10 \\
\hline Ayder'de ulaşım olanakları yeterlidir. & 3,60 & 1,00 \\
\hline Ayder Kardan Adam Şenliği, yerel ekonomiyi canlandırmaktadır. & 3,63 & 1,00 \\
\hline $\begin{array}{l}\text { Ayder Kardan Adam Şenliği, yerel halka becerilerini sergilemek ve kazanç sağlamak } \\
\text { için firsatlar sağlamaktadır. }\end{array}$ & 3,51 &, 85 \\
\hline \multicolumn{3}{|l|}{ Çevresel Etkiler } \\
\hline Ayder Kardan Adam Şenliği, doğal çevrenin korunmasını sağlamaktadır. & 3,51 & ,99 \\
\hline Ayder Kardan Adam Şenliği, gürültü ve çevre kirliliğine neden olmaktadır. & 3,58 & 1,18 \\
\hline Ayder'de çevre temizliği yeterlidir. & 2,69 & 1,40 \\
\hline Ayder Kardan Adam Şenliği süresince trafik yŏgunluğu vardır. & 3,75 & ,98 \\
\hline Ayder Kardan Adam Şenliği süresince otopark sorunu vardır. & 3,76 & 1,11 \\
\hline Ayder Kardan Adam Şenliği süresince gürültü düzeyi rahatsızlık vericidir. & 3,36 & 1,30 \\
\hline \multicolumn{3}{|l|}{ Kişisel Kazanımlar } \\
\hline Ayder Kardan Adam Şenliği, hoş ve eğlenceli vakit geçirmemi sağladı. & 3,20 & 1,05 \\
\hline Ayder Kardan Adam Şenliği, günlük stresimi atmamı să̆ladı. & 3,71 & 910 \\
\hline Ayder Kardan Adam Şenliği etkinlikleri beklentilerimi karşıladı. & 3,32 & ,935 \\
\hline Ayder Kardan Adam Şenliği, yörenin kültürü ile ilgili bilgimi artırdı. & 3,47 & 1,13 \\
\hline Ayder Kardan Adam Şenliği, genel kültürümü artırdı. & 3,23 & ,94 \\
\hline $\begin{array}{l}\text { Ayder Kardan Adam Şenliği sayesinde kültürel ve sosyal faaliyetlerin gerekliliğini } \\
\text { anladım. }\end{array}$ & 3,62 &, 80 \\
\hline Ayder Kardan Adam Şenliği, yerel değerlere bağlılı̆̆ımı artırdı. & 3,50 & ,86 \\
\hline \multicolumn{3}{|l|}{ Genel Etkiler } \\
\hline Ayder Kardan Adam Şenliği’nin iyi bir şekilde düzenlendiğini düşünüyorum. & 2,97 & 1,01 \\
\hline Ayder Kardan Adam Şenliği’nin programını ilgi çekici buluyorum. & 3,27 & ,92 \\
\hline Ayder Kardan Adam Şenliği’nin tanıtımının iyi yapıldığını düşünüyorum. & 3,02 & 1,08 \\
\hline Ayder Kardan Adam Şenliği'nde düzenlenen etkinlikler yeterli düzeydedir. & 2,87 &, 85 \\
\hline Ayder Kardan Adam Şenliği, Ayder'in tanıtımına katkı sağlamaktadır. & 3,55 & ,98 \\
\hline Ayder Kardan Adam Şenliği, yörenin ülke çapında tanınmasını kolaylaştırmaktadır. & 3,30 & 1,15 \\
\hline Ayder Kardan Adam Şenliği, amacına uygun düzenlenmektedir. & 3,51 & ,92 \\
\hline Ayder Kardan Adam Şenliği, yerel turizmi geliştirmektedir. & 3,71 & ,90 \\
\hline Ayder Kardan Adam Şenliği, suiistimal edilmektedir (fiyat artırma, çıkar sağlama vb.). & 2,73 & 1,33 \\
\hline
\end{tabular}

Yapılan değişken analizi sonucuna göre; aritmetik ortalama ve standart sapmalarına göre ön plâna çıkan önermeler şu şekildedir: 
Genel olarak en yüksek katılım oranına sahip olan önerme; "Ayder Kardan Adam Şenliği sayesinde yeni insanlarla tanışma firsatım oldu" ifadesidir. En düşük katılım oranına sahip olan önerme ise; "Ayder'de çevre temizliği yeterlidir" ifadesidir. Ayder Kardan Adam Şenliği'nin olumlu etkileri değerlendirildiğinde ise; “Ayder Kardan Adam Şenliği, yerel turizmi geliştirmektedir" ve "Ayder Kardan Adam Şenliği, Ayder'in tanıtımına katk1 sağlamaktadır" ifadeleri, ziyaretçi algılarının olumlu yönde olduğunu belirtmektedir. Katılımcılara yöneltilen önermeler, farklı kategoriler bazında değerlendirildiğinde ön plana çıkan ifadeler ise şu şekilde özetlenebilmektedir:

Sosyo-kültürel etkiler kategorisinde en yüksek katılım oranı; "Ayder Kardan Adam Şenliği, geleneksel kültürün gelecek kuşaklara aktarılmasını sağlamaktadır" ve "Ayder Kardan Adam Şenliği sayesinde yeni insanlarla tanışma firsatım oldu" ifadelerine aittir. Ekonomik etkiler incelendiğinde ise; "Ayder'deki konaklama fiyatları uygundur" ve "Aydler'deki yeme-içme fiyatları uygundur" ifadelerine genel katılımın yüksek olmasıyla, ziyaretçilerin ekonomik yönden şenliğe karşı algılarının olumlu olduğunu söylemek mümkün olabilmektedir. Çevresel etkiler kategorisi değerlendirildiğinde ise en yüksek katılım oranları; "Ayder Kardan Adam Şenliği süresince otopark sorunu vardır" ve "Ayder Kardan Adam Şenliği süresince trafik yoğunluğu vardır" ifadeleridir. Bu durum, şenlik süresince bölgenin alt yapı olanaklarının ve taşıma kapasitesi analizinin iyi yapılmasının gerekliliğini ortaya çıkarmaktadır. Kişisel kazanımlar kategorisinde ise; "Ayder Kardan Adam Şenliği, günlük stresimi atmamı sağladı" ve "Ayder Kardan Adam Şenliği sayesinde kültürel ve sosyal faaliyetlerin gerekliliğini anladım" ifadelerine yüksek oranda katılım sağlanmış olması ile birlikte ziyaretçilerin bu anlamda algılarının olumlu olduğunu söylemek mümkün olabilmektedir.

\section{Hipotezlerin Test Edilmesine İlişkin Bulgular}

Hipotezleri test etmek için Mann - Whitney U ve Kruskal - Wallis H analizlerinden yararlanılmıştır. Mann - Whitney U Testi, aralıksız ölçülen iki bağımsız grup arasındaki farklılıkların testi için kullanılır. Bu test, bağımsız örnekler için uygulanan t-testlerinin parametrik olmayan alternatifidir (Kalayc1, 2014: 99). Bu araştırmada, iki gruba sahip demografik değişkenlerde, gruplar arasında Ayder Kardan Adam Şenliği'nin etkilerine yönelik düşüncelerin farklılık gösterip göstermediğini belirlemek amacıyla kullanılmaktadır. Tablo 4'te Mann - Whitney U Testi sonuçlarına ilişkin bulgular yer almaktadır.

Tablo 4. Mann - Whitney U Testi Sonuçları

\begin{tabular}{|l|c|c|c|c|c|}
\hline & $\begin{array}{c}\text { Sosyo- } \\
\text { Kültürel }\end{array}$ & Ekonomik & Çevresel & $\begin{array}{c}\text { Kişisel } \\
\text { Kazanım }\end{array}$ & Genel Etkiler \\
\hline \multicolumn{7}{|c|}{ Cinsiyet } \\
\hline Mann-Whitney U & 3982,000 & 4483,500 & 4438,000 & 3865,500 & 3850,500 \\
\hline Wilcoxon W & 8353,000 & 8854,500 & 8809,000 & 8236,500 & 8221,500 \\
\hline Z & $-1,405$ &,- 072 &,- 192 & $-1,715$ & $-1,753$ \\
\hline Sig. (2-tailed) &, 160 &, 943 &, 848 &, 086 &, 080 \\
\hline \multicolumn{7}{|c|}{ Daha Önce Bir Şenliğe Katılıp Katılmama Durumu } \\
\hline Mann-Whitney U & 2431,500 & 2876,500 & 2737,000 & 2793,000 & 2843,500 \\
\hline Wilcoxon W & 3172,500 & 14504,500 & 14365,000 & 3534,000 & 3584,500 \\
\hline Z & $-1,517$ &,- 038 &,- 501 &,- 316 &,- 148 \\
\hline Sig. (2-tailed) &, 129 &, 970 &, 617 &, 752 &, 883 \\
\hline
\end{tabular}


Hipotez 1. Yerli turistlerin Ayder Kardan Adam Şenliği’ne yönelik algılart cinsiyete göre anlamlı farklılık göstermektedir.

Araştırmaya katılan ziyaretçilerin, Ayder Kardan Adam Şenliği’nin etkilerine yönelik düşüncelerinin cinsiyet değişkenine göre anlamlı bir fark gösterip göstermediğini belirlemek amaciyla yapılan Mann-Whitney U Testi sonucunda; grup ortalamaları arasindaki fark istatistiksel açıdan anlamlı bulunmamıştır $(p=0,160>0,05 ; p=0,943>0,05 ; p=0,848>0,05$; $p=0,086>0,05 ; p=0,080>0,05)$. Ortalamalar, ziyaretçilerin Ayder Kardan Adam Şenliği'nin etkilerine yönelik genel tutumlarının arasında cinsiyete göre fark olmadığını göstermektedir. Bu durumda; Hipotez 1 reddedilmiştir.

Hipotez 2. Yerli turistlerin Ayder Kardan Adam Şenliği'ne yönelik alguları daha önce bir şenliğe katılıp katılmama durumuna göre anlamlı farklılık göstermektedir.

Araştırmaya katılan ziyaretçilerin, Ayder Kardan Adam Şenliği'nin etkilerine yönelik düşüncelerinin daha önceden bir şenliğe katılıp katılmama durumlarına göre anlamlı bir fark gösterip göstermediğini belirlemek amacıyla yapılan Mann-Whitney U Testi sonucunda; grup ortalamaları arasındaki fark istatistiksel açıdan anlamlı bulunmamıştır $(p=0,129>0,05$; $p=0,970>0,05 ; p=0,617>0,05 ; p=0,752>0,05 ; p=0,883>0,05)$. Ortalamalar, ziyaretçilerin Ayder Kardan Adam Şenliği'nin etkilerine yönelik genel tutumlarının arasında daha önceden bir şenliğe katılıp katılmama durumlarına göre fark olmadığını göstermektedir. Bu durumda; Hipotez 2 reddedilmiştir.

Kruskal - Wallis H Testi, gruplar arası tek yönlü varyans analizinin parametrik olmayan alternatifidir. Bu analiz, sürekli değişkenlere sahip üç ya da daha fazla grup için karşılaştırma yapmayı sağlar (Kalaycı, 2014: 106). Bu araştırmada, üç veya daha fazla gruba sahip demografik değişkenlerde, gruplar arasında Ayder Kardan Adam Şenliği'nin etkilerine yönelik düşüncelerin farklılık taşıyıp taşımadığını belirlemek amaçyla kullanılmaktadır. Kruskal - Wallis H Testi sonuçlarına ilişkin bulgular Tablo 5 'te yer almaktadır.

Tablo 5. Kruskal - Wallis H Testi Sonuçları

\begin{tabular}{|l|c|c|c|c|c|}
\hline & $\begin{array}{c}\text { Sosyo- } \\
\text { Kültürel }\end{array}$ & Ekonomik & Çevresel & Kişisel Kazanım & Genel Etkiler \\
\hline \multicolumn{7}{|c|}{ Yaş } \\
\hline Chi-Square &, 092 &, 277 &, 655 &, 231 & 1,141 \\
\hline df & 1 & 1 & 1 & 1 & 1 \\
\hline Asymp. Sig. &, 761 &, 599 &, 418 &, 631 &, 285 \\
\hline \multicolumn{7}{|c|}{ İkamet Edilen Yer } \\
\hline Chi-Square &, 464 &, 012 & 9,594 &, 183 & 3,226 \\
\hline df & 1 & 1 & 1 & 1 & 1 \\
\hline Asymp. Sig. &, 496 &, 912 &, 002 &, 669 &, 072 \\
\hline \multicolumn{7}{|c|}{ Ayder'de Kalınan Süre } \\
\hline Chi-Square &, 630 &, 172 & 2,568 & 1,296 &, 909 \\
\hline df & 1 & 1 & 1 & 1 & 1 \\
\hline Asymp. Sig. &, 427 &, 679 &, 109 &, 255 &, 340 \\
\hline
\end{tabular}

Hipotez 3. Yerli turistlerin Ayder Kardan Adam Şenliği’ne yönelik algıları yaşa göre anlamlı farklılık göstermektedir. 
Araştırmaya katılan ziyaretçilerin ifadelere verdikleri yanıtların puan ortalamalarının yaş değişkeni açısından anlamlı bir farklılık gösterip göstermediğini belirlemek amacıyla yapılan Kruskal-Wallis $\mathrm{H}$ Testi sonuçlarına göre; grup ortalamaları arasındaki fark anlamlı bulunmamıştır ( $p=0,761>0,05 ; p=0,599>0,05 ; p=0,418>0,05 ; p=0,631>0,05 ; p=0,285>0,05)$. Ortalamalara göre, ziyaretçilerin Ayder Kardan Adam Şenliği'nin etkilerine yönelik genel tutumlarının arasında yaş değişkenine göre fark olmadığını söylemek mümkündür. $\mathrm{Bu}$ durumda; Hipotez 3 reddedilmiştir.

Hipotez 4. Yerli turistlerin Ayder Kardan Adam Şenliği’ne yönelik alglları ikamet edilen yere göre anlaml farklılık göstermektedir.

Araştırmaya katılan ziyaretçilerin ifadelere verdikleri yanıtların puan ortalamalarının ikamet edilen yer açısından anlamlı bir farklılık gösterip göstermediğini belirlemek amacıyla yapılan Kruskal-Wallis H Testi sonuçlarına göre; grup ortalamaları arasındaki fark "Çevresel Etkiler" kategorisinde anlamlı bulunmuştur $(p=0,002<0,05)$. Bu sonuç; farklı ikamet yerlerinin Ayder Kardan Adam Şenliği'nin çevresel etkilerine yönelik tutumlarına ait puanları arasında anlamlı bir farklılık olduğunu göstermektedir. Farklılığın hangi gruptan kaynaklandığını belirlemek üzere uygulanan test sonucunda; Rize merkezde ikamet eden ziyaretçilerin puan ortalamalarının $(x=51,99)$, Çamlıhemşin'de ikamet eden ziyaretçilere $(x=35,09)$ oranla daha yüksek olduğunu söylemek mümkündür. Bu durumda da; Hipotez 4 kısmen kabul edilmiştir.

Hipotez 5. Yerli turistlerin Ayder Kardan Adam Şenliği'ne yönelik algıları Ayder'de kalınan süreye göre anlamlı farklılık göstermektedir.

Araştırmaya katılan ziyaretçilerin ifadelere verdikleri yanıtların puan ortalamalarının Ayder'de kalınan süre açısından anlamlı bir farklılık gösterip göstermediğini belirlemek amacıyla yapılan Kruskal-Wallis $\mathrm{H}$ Testi sonuçlarına göre; grup ortalamaları arasındaki fark anlamlı bulunmamıştır $\quad(p=0,427>0,05 ; \quad p=0,679>0,05 ; \quad p=0,109>0,05 ; \quad p=0,255>0,05$; $p=0,340>0,05)$. Ortalamalar, ziyaretçilerin Ayder Kardan Adam Şenliği'nin etkilerine yönelik genel tutumlarının arasında Ayder'de kalınan süre açısından fark olmadığını göstermektedir. $\mathrm{Bu}$ durumda; Hipotez 5 reddedilmiştir.

\section{SONUÇ VE ÖNERILER}

Bir yörede, yöresel kültürün ve yöresel kimliğin ortaya koyulduğu ve tanıtıldığ 1 en önemli faaliyetlerden birisi yöresel şenliklerdir. Şenliklerin, bölgesel ve yerel kültürleri tanıtma rolünün yanında, şenliğe katılan ziyaretçilere de farklı deneyimler sunabilme avantajı bulunmaktadır. Yapılan bu çalışma ile etkinlik turizmi kapsamında değerlendirilen yöresel şenliklerin; sosyo-kültürel, ekonomik, çevresel ve genel etkileri ile kişisel kazanımlar, ziyaretçilerin bakış açısıyla değerlendirilmiştir.

Yerel etkinlikler kapsamında şenliklerin düzenlendikleri bölgeye sosyo-kültürel, ekonomik ve çevresel etkilerini incelemek amacıyla Ayder Yaylası Kardan Adam Şenliği'ni ziyaret eden yerli turistlerden elde edilen veriler 1şı̆̆ında; katılımcıların demografik özellikleri ve seyahat alışkanlıkları şöyle özetlenebilir; katılımcıların \%42,1'si, 21-30 yaş aralığında bulunmaktadır. Şenliğe katılan ziyaretçilerin büyük çoğunluğu $(\% 49,5)$, Rize dışında ikamet etmektedir. Ayder Kardan Adam Şenlikleri'ne ilk kez katılanların sayısı genel ortalamanın $(\% 50,5)$ üzerinde bulunmaktadır ve ziyaretçilerin büyük çoğunluğu $(\% 80,0)$, daha önceden başka bir şenliğe de katılmışlardır. Ayder Kardan Adam Şenliği'nin arkadaş veya akraba tavsiyesi 
şeklinde duyurumu daha yaygındır $(\% 54,7)$. Ziyaretçilerin büyük çoğunluğunun $(\% 55,3)$, tekrar şenliğe gelme niyetindedirler ve genel olarak $(\% 79,5)$ katılımcılar, Ayder Kardan Adam Şenliği'ni çevrelerine de tavsiye etme eğilimindedirler. Buradan hareketle; Ayder Kardan Adam Şenliği’nde ağızdan ağıza ve deneyimsel pazarlamanın önemine dikkat çekmek gerekmektedir. Özellikle şenliğin hazırlık aşamasında bu verilerden yararlanılması, hem yerel halkın hem de ziyaretçilerin memnuniyet düzeylerinin artmasına neden olabilecektir. $\mathrm{Bu}$ anlamda, çevresel etkilerin, özellikle büyük etkinliklerle ilgili olarak son yıllarda ön plana çıktığının altını çizen Çakıcı ve Yavuz (2012: 11), son dönemde önemli spor etkinliklerinin büyük bir bölümünün, sürdürülebilir gelişme ve çevresel eğitim konularına odaklandığını ifade etmektedirler. Söz konusu durum da, Ayder Kardan Adam Şenliği için yol gösterici olmalı ve sürdürülebilirlik olgusuna hassasiyet gösterilmelidir.

Çalışma sonucunda elde edilen veriler diğer benzer çalışmalarla da benzer nitelik taşımaktadır. Turistlerin seyahat motivasyonlarının, yerel etkinliklerin sosyo-kültürel, ekonomik ve çevresel etkilerini algılamalarında farklılık yaratması söz konusudur (Boo ve diğerleri, 2009: 56). Bu sebeple ileride yapılacak çalışmalarda yerli ya da yabancı turistlerin seyahat motivasyonları üzerine odaklanılması önerilebilmektedir. Tüm bunlardan yola çıkarak, yöresel etkinliklerin kültürel ve sosyal alanların tümünde bir kazanım sağlayabilecek nitelikte turizm faaliyeti olduğu ifade edebilmektedir. Bu bağlamda; hem yerel halk, hem de katılımcılar için memnuniyet anketleri düzenlenip, yerel halkın ve dışarıdan gelen katılımcı kitlesinin istek ve beklentileri ortaya konularak bir düzenleme yapılma yoluna gidilebilir. Yine benzer şekilde, bu tür etkinliklerin tüm yıla ve farklı bölgelere yayılması, zamanda ve mekânda yığılmaların önlenmesini sağlayabilecek bir fırsat olarak değerlendirilebilir.

Yöreye özgü kültürel unsurların, başka bir yerde tüketilme olanağının bulunmaması ve sadece o bölgenin kültürü, tarihi ve çevresinin etkileşimi ile birlikte ortaya çıkması, ziyaretçilere eşsiz bir deneyim sunmaktadır. İkamesinin bu denli güç bulunduğu kültürel miras konusunda öncelikle yerel halk bilinçlendirilmeli ve yerel yönetimler, özel sektör paydaşları ile birlikte eşgüdümlü çalışmalar yürütülmelidir. Ayder Kardan Adam Şenliği kapsamında, yöreye ait yöresel ve geleneksel el sanatını içeren ürünlerin üretilmesi, sergilenmesi ve tanıtılması bölgesel ve yerel kalkınma açısından da önem arz etmektedir. Aynı zamanda, yörenin sahip olduğu diğer turistik ürünlerle entegre edilerek turistik ürün şeklinde sunulması yörenin çekiciliğini de artırabilecektir.

\section{REFERENCES}

- AMBRÓSIO, Vitor; Leila MANUEL ve Teresa FARIA; (2011), "Events and Destination Management - Car Launch In Lisbon", International Journal of Management Cases, 13(4), pp.331-337.

- ATAK, Onur (2009), Türk Turizminin Tanıtımında Festivallerin Yeri ve Önemi: Antalya Örneği, İstanbul Üniversitesi Sosyal Bilimler Enstitüsü Yayınlanmamış Yüksek Lisans Tezi, İstanbul.

- BİLGİLI, Bilsen; Önder YAĞMUR ve Hakan YAZARKAN;(2012), "Turistik Ürün Olarak Festivallerin Etkinlik ve Verimliliği Üzerine Bir Araştırma (Erzurum-Oltu Kırdağ Festivali Örneği)",Uluslararası Sosyal ve Ekonomik Bilimler Dergisi, 2(2), ss.117-124. 
- BOO, Soyoung; Miyoung KIM ve David L. JONES;(2009), "Comparative Analysis of Travel-Related Characteristics Between Special Event Attendees and Non-Attendees in a Metropolitan City", Journal ofConvention\&EventTourism, 10(1),pp.50-71.

- CHEN,Sandy C.; (2011), "Residents' Perceptions of the Impact of Major Annual Tourism Events in Macao: Cluster Analysis", Journal of Convention \& Event Tourism, 12(2), pp.106-128.

- ÇAKICI, Celil ve Gülser YAVUZ(2012), “2013 Akdeniz Oyunları Bağlamında Spor Etkinlikleri ve Olası Etkileri”,1. Doğu Akdeniz Turizm Sempozyumu, 20-22 Nisan 2012, ss.2-15.

- ÇELİK, Ayşe (2009), Destinasyon Pazarlama Unsuru Olarak Etkinlik Turizmi ve Etkileri - İstanbul Örneği, Gazi Üniversitesi Eğitim Bilimleri Enstitüsü Yayınlanmamış Yüksek Lisans Tezi, Ankara.

- ÇULHA, Osman; (2008), "Kültür Turizmi Kapsamında Destekleyici Turistik Ürün Olarak Deve Güreşi Festivalleri Üzerine Bir Alan Çalışması", Journal of Yasar University, 3(12), ss.1827-1852.

- EKİN, Yakın (2011), Etkinlik Turizmi Kapsamında Festivaller ve Antalya Altın Portakal Film Festivali'nin Yerel Halk Üzerindeki Sosyal Etkileri Konulu Bir Araştırma, Akdeniz Üniversitesi Sosyal Bilimler Enstitüsü Yayınlanmamış Doktora Tezi, Antalya.

- GETZ, Donald; (2008), “Event Tourism: Definition, Evolution and Research”, Tourism Management, 29,ss.403-428.

- GÜL, Kudret; Barış ERDEM ve Melike GÜL; (2013), "Yerel Festivallerin Etkinliğine Bağlı Ziyaretçi Kazanımları: Sındırgı Yağcıbedir Festivali Örneği”, Süleyman Demirel Üniversitesi İktisadi ve İdari Bilimler Fakültesi Dergisi, 18(2), ss.213239.

- GÜRSOY, Doğan; Kyungmi KIM and Muzaffer UYSAL; (2004), "Perceived Impacts of Festivals and Special Events by Organizers: An Extension and Validation", Tourism Management, 25,pp.171-181.

- HODUR, Nancy M. ve F. Larry LEISTRITZ; (2006), Estimating the Economic Impact of Event Tourism", Journal of Convention \& EventTourism, 8(4),pp.63-79.

- HORNG, Jeou-Shyan; Ching-Shu SU ve Siu-Ian Amy SO; (2013), "Segmenting Food Festival Visitors: Applying the Theory of Planned Behavior and Lifestyle", Journal of Convention \& Event Tourism, 14(3),pp.193-216.

- JACKSON, Leonard A.; (2008), “Residents' Perceptions of the Impacts of Special Event Tourism”, Journal of Place Management and Development, 1(3), pp.240 255.

- JEPSON, A., S. WILTSHIER ve A. CLARKE (2008), “Community Festivals: Involvement and Inclusion", CHME International Research Conference, 14th - 16th May 2008, Glasgow. 
- JONES, Calvin; (2001), "Mega-Events and Host-Region Impacts: Determining the True Worth of the 1999 Rugby World Cup", International Journal of Tourism Research, 3, pp.241-251.

- KALAYCI, Şeref; (2014), SPSS Uygulamalı Çok Değişkenli İstatistik Teknikleri, Altıncı Baskı, Asil Yayın Dağıtım, Ankara, ss.426.

- KARAGÖZ, Deniz (2006), Etkinlik Turizmi ve Etkinlik Turizmi Biağlamında Yabancı Ziyaretçi Harcamalarının Ekonomiye Etkisi: Formula 12005 Türkiye Grand Prix Örneği, Anadolu Üniversitesi Sosyal Bilimler Enstitüsü Yayınlanmamış Yüksek Lisans Tezi, Eskişehir.

- KIZILIRMAK, İsmail; (2006), “Türkiye'de Düzenlenen Yerel Etkinliklerin Turistik Çekicilik Olarak Kullanılmasına Yönelik Bir İnceleme”, Sosyal Bilimler Dergisi, 15, ss.181-196.

- KIŞ̦íOĞLU, Erdal ve M. Selim SELVİ; (2013), "Yerel Etkinliklerin Tekirdağ'ın Destinasyon İmajına Etkisi: Yerel Paydaşlar Açısından Bir Değerlendirme”, IAAOOJ Social Science, 1(1), ss.68-102.

- KOH, Khoon Y. ve Anita A. JACKSON; (2006), "Special Events Marketing", Journal of Convention \& Event Tourism, 8(2), pp.19-44.

- KÖMÜRCÜ, Gizem Beyaz (2013), Etkinlik Turizmi Çeşidi Olarak Festivaller: Bozcaada Yerel Tatlar Festivali Örneği, Çanakkale Onsekiz Mart Üniversitesi Sosyal Bilimler Enstitüsü Yayınlanmamış Yüksek Lisans Tezi, Çanakkale.

- KÖMÜRCÜ, Gizem Beyaz; Mustafa BOZ ve Şule AYDIN TÜKELTÜRK; (2014), "Festivals as a Type of Event Tourism: Tenedos Local Flavours Festival Sample Case", İstanbul Ticaret Üniversitesi Sosyal Bilimleri Dergisi, 13(25), ss.221-237.

- MATHESON, Catherine M.; Russell RIMMER ve Ross TINSLEY; (2014), "Spiritual Attitudes and Visitor Motivations at the Beltane Fire Festival, Edinburgh", Tourism Management 44, pp.16-33.

- MEYDAN UYGUR, Selma ve Ayşe ÇELIKK; (2010), "Etkinlik Turizminin Algılanan Sosyo-Ekonomik etkilerini Belirlemeye Yönelik İstanbul Destinasyonunda Bir Araştırma, İşletme Fakültesi Dergisi, 11(1), ss.35-50.

- MORGAN, Ash ve Simon CONDLIFFE; (2006), "Measuring the Economic Impacts of Convention Centers and Event Tourism",Journal of Convention \& Event Tourism, 8(4), ss.81-100.

- ÖZCAN, Esin; (2005), "Bolu İlinde Turizmi Etkileyen Faktörler İle Doğal, Tarihi ve Kültürel Turizm Değerleri”, Gazi Eğitim Fakültesi Dergisi, 25(1), ss.55-75.

- POLAT, Serkan, Semra AKTAŞ POLAT ve Mine HALİS; (2013), "Kent Kimliği Kapsamında Festivallerin Değerlendirilmesi: Uluslararası Altın Safran Film Festivali Örneği”, Turizm ve Araştırma Dergisi, 2(1), ss.48-63.

- POPESCU, Ruxandra-Irina ve Răzvan-Andrei CORBOŞ; (2012), "The Role of Festivals and Cultural Events in the Strategic Development of Cities. 
Recommendations for Urban Areas in Romania”, Informatica Economică, 16 (4), ss.19-28.

- ŞEBİN, Kenan; A. Gökhan YAZICI; Erdoğan TOZOĞLU; Özgür BOSTANCI ve M. Fatih KARAHÜSEYINOĞLU; (2010), "Yöre Halkının Erzurum Kış Sporları Turizmi İle İlgili Sosyo-Kültürel ve Ekonomik Beklentileri”, Atabesbd, 12(1), ss.18-29.

- YANG, Jie; Xuehui ZENG ve Yingkang GU; (2010), “Local Residents' Perceptions of the Impact of 2010 EXPO", Journal of Convention \& Event Tourism, 11(3), pp.161-175.

- YEOMAN, Ian; Martin ROBERTSON ve Una MCMAHON-BEATTIE; (2004), "Visitor Management for Festivals and Events", iç. Ian YEAMAN, Martin ROBERTSON, Jane AL

- KNIGHT, Siobhan DRUMMOND and Una MCMAHON-BEATTIEE (Ed.), Festival and Events Management: An International Arts and Culture Perspective, Butterworth-Heinemann, Great Britain, pp.64-79.

\section{INTERNET REFERENCES}

- http://www.tanitma.gov.tr/TR,50394/festivaller-fuarlar-ve-yerel-etkinlikler-2013.html (25.12.2014). 